\title{
Textural properties of low-fat set-type yoghurt depending on mTG addition
}

\author{
doi: $10.15567 /$ mljekarstvo.2016.0307 \\ Lívia Darnay ${ }^{*}$, Ágota Koncz ${ }^{1}$, Éva Gelencsér ${ }^{2}$, Klára Pásztor-Huszár $^{1}$, László Friedrich \\ ${ }^{1}$ Corvinus University of Budapest, Faculty of Food Science, \\ Department of Refrigeration and Livestock Products Technology, Budapest, Hungary \\ ${ }^{2}$ Unit of Biology, National Agricultural Research and Innovation Centre Food Science Research Institute, \\ 1022 Budapest, Herman Ottó út 15, Hungary \\ Accepted - Prihvaćeno: 16.05.2016.

\begin{abstract}
Our aim was to determine how 0.5-2 U/g non-inactivated mTG affects the $\mathrm{pH}$ development and apparent viscosity during fermentation. Furthermore we wished to examine how the enzyme addition could change protein structure, gel strength and sensory characteristics by healthy low-fat set-type yoghurt product. Therefore commercial mTG enzyme preparation was added in different concentrations $(0.5-2.0 \mathrm{U} / \mathrm{g}$, in $0.5 \mathrm{U} / \mathrm{g}$ steps $)$ to $1.5 \%$ bovine milk simultaneously with DVS starter culture. Our study revealed that enzyme dosage (0.5-2 U/g protein) had no impact on $\mathrm{pH}$ development and apparent viscosity during fermentation when manufacturing low-fat (1.5\%) set-type yoghurt. The addition of $\mathrm{mTG}$ contributed to $38 \%$ more whey retention with incorporation of $\beta$-casein, and caused $44 \%$ higher gel strength up to a level of $1 \mathrm{U} / \mathrm{g}$ protein.
\end{abstract}

Received - Prispjelo: 21.10.2015.

Key words: fermentation, low-fat yoghurt, transglutaminase, gel strength, apparent viscosity, sensory evaluation

\section{Introduction}

Yoghurt is among the best known and most popular fermented milk products in the world. This popularity includes great possibilities in the field of product development and R\&D. Microbial transglutaminase is nowadays primarily used to improve the texture of set-type and stirred yoghurts made of low-fat (Iličić et al., 2008; Guyot and Kulozik, 2011) or even non-fat (Ozer et al., 2007) bovine milk to make a product with appropriate creaminess, mouthfeel and spoonability.

The enzyme dosage is in most cases standardised according to the manufacturer's recommendation to $1 \mathrm{U} / \mathrm{g}$ protein concentration (Gauche et al., 2007; Wroblewska et al., 2010; Yüksel and Erdem, 2010; Sanli et al., 2010). Guyot and Kulozik (2011) analysed the effect of $(0.5,1,3$ and $10 \mathrm{U} / \mathrm{g}$ protein) mTG treated skim milk powder on the viscosity of stirred skim milk yoghurt, and find out that the addition of mTG treated skim milk powder (where mTG was inactivated by heat treatment and spray drying) did not influence on structural defects during the storage of final product. The same effect was observed at direct incubation (Bönisch et al., 2007a; Demirkaya and Ceylan, 2009; Lorenzen et al., 2002; Ozer et al., 2007; Yüksel and Erdem, 2010). Nevertheless, a more stable structure during 20-day storage with lower whey loss was observed. Iličić et al. (2008) investigated the effect of different enzyme dosages (0.02, 0.06 and $0.12 \%$ w/w) using $0.1 \%$ and $0.5 \%$ bovine milk. According to their results in case of stirred probiotic yoghurt the active mTG caused prolonged fermentation at both milk fat levels but changes in viscosity could be detected only at the highest enzyme dosage $(0.12 \% \mathrm{w} / \mathrm{w}$, $0.4 \mathrm{U} / \mathrm{g}$ protein) during 10 days of storage. 
According to the majority of articles in the literature, a temperature above $70{ }^{\circ} \mathrm{C}$ and up to 10 minutes holding time is needed to ensure total inactivation of the enzyme (Bönisch, et al., 2007a; Gauche et al., 2007; Iličić et al., 2008; Wroblewska et al., 2010) although this inactivation step seems to be too expensive for the dairy industry and therefore often neglected. While the possibility of negative structural effects due to mTG activity during storage period seems to be obvious, it is still a debatable topic whether active mTG may cause longer fermentation time due to a possible change of available amino acids for the growth of lactobacilli (Færgemand et al., 1999; Lorenzen et al., 1998). Neve et al., (2001) stated that in case of enzyme-treated skim milk the fermentation time is not prolonged since yoghurt starter bacteria are able to break down sufficient amount of casein before the crosslinking happens. Moreover, they observed a stabilizing effect of mTG on L. delbrueckii subsp. bulgaricus after 2 weeks of storage time. Concerning the time and cost of additional heat treatment in yoghurt process technology our aim was to determine how 0.5-2 $\mathrm{U} / \mathrm{g}$ non-inactivated $\mathrm{mTG}$ affects the $\mathrm{pH}$ development and apparent viscosity during fermentation and how it changes the milk protein distribution, gel strength and sensorial characteristics in $1.5 \%$ lowfat set-type yoghurt.

\section{Material and methods}

Milk, starter culture, mTG enzyme

ESL milk (protein: $3 \%$, fat: $1.5 \%$, carbohydrates: $4.6 \%$ ) was obtained from Alföldi Tej Ltd. (Hungary). A freeze-dried yoghurt starter culture named YF-L811 (50 U/pouch, Chr. Hansen A/S, Denmark) consisting Streptococcus thermophilus and Lactobacillus delbrueckii subsp. bulgaricus in 1:1 ratio was used as it is specially developed for set-type yoghurts with very high body, very mild flavour, very low post acidification. One pouch of the DVS culture is designed for the inoculation of $250 \mathrm{~L}$ milk. We inoculated only $2 \mathrm{~L}$ of milk for each yoghurt therefore a mother culture ( 1 pouch incubated at $43{ }^{\circ} \mathrm{C}$ in $500 \mathrm{~mL}$ of $2.8 \%$ UHT milk for $2 \mathrm{~h}$ ) was used in $1.6 \% \mathrm{v} / \mathrm{w}$ to start the fermentation. This inoculation allowed also to finalise acidification (reach pH 4.8) in 3 hours. Microbial transglutaminase derived from Activa YG enzyme preparation (Barentz Hungary Ltd., nominal activity: 100 U/g protein) was used, which contains only $1 \% \mathrm{w} / \mathrm{w}$ mTG (Bönisch et al., 2007) beside of maltodextrin, lactose and safflower oil.

\section{Yoghurt production procedure}

Four different enzyme dosages $(0.5 \mathrm{U} / \mathrm{g}$ protein; $1 \mathrm{U} / g$ protein; $1.5 \mathrm{U} / g$ protein; $2 \mathrm{U} / g$ protein) were used for manufacturing of low-fat (1.5\%) settype yoghurt beside a control one (without enzyme addition). Altogether 5 yoghurts (marked as control, $0.5 \mathrm{mTG}, 1 \mathrm{mTG}, 1.5 \mathrm{mTG}, 2 \mathrm{mTG}$ ) were made for one experiment, which was repeated once. The yoghurt milk was tempered to $43{ }^{\circ} \mathrm{C}$, and starter culture (YF-L811) and commercial enzyme preparation (Activa YG) were added simultaneously. The enzyme was not inactivated, consistent with common practice in Hungarian food industry due to the high cost of extra heat treatment. The inoculated and partially enzyme treated milk were then distributed in $250 \mathrm{~mL}$ PP plastic containers and incubated at $43^{\circ} \mathrm{C}$. The fermentation process was followed by $\mathrm{pH}$ and rheological measurements. Fermentation was already stopped at $\mathrm{pH} 4.8$ to avoid over-acidification (observed under $\mathrm{pH}$ 4.6) during the time needed to cool down the yoghurt from $43{ }^{\circ} \mathrm{C}$ to $10^{\circ} \mathrm{C}$. Yoghurt samples were kept in a household refrigerator at $5^{\circ} \mathrm{C}$ overnight for aging.

\section{Monitoring lactic acid fermentation}

The $\mathrm{pH}$ was measured every 20 minutes with Testo 206 portable pH meter (Testo AG., Germany) until $\mathrm{pH} 4.8$ was reached. As the shear rate $(\mathrm{D}, 1 / \mathrm{s})$ measured between 10-100 1/s models the chewing and swallowing properties of yoghurt (STEFFE 1996; MEZGER 2006) the shear stress measured at $57.2 \mathrm{l} / \mathrm{s}$ shear rate was determined during fermentation with Rheomat 115 (Contraves, Switzerland) rotational viscometer using the conical measure head type 145 . The samples were measured at the fermentation temperature of $43^{\circ} \mathrm{C}$. Every measurement was done in duplicate with $100 \mathrm{~g}$ of samples. Shear stress $(\tau, \mathrm{Pa})$ was calculated from the read values of the instrument $(\alpha)$ multiplied by the factor of the measure system type $145(\mathrm{z}=195.5)$. Consistency factor (K) was calculated from the slopes of the shear-stress curves obtained in the range of 0-57.2 1/s shear rate. Flow-index (n) was calculated as $\mathrm{n}=\log \mathrm{D}(\tau-\tau \mathrm{o} / \mathrm{K})$. Apparent viscosity $\left(\eta, \mathrm{Pa}^{*} \mathrm{~s}\right)$ is the shear stress $(\tau)$ divided by the instrument factor $(z=195.5)$. 


\section{Characteristics of yoghurt and whey}

Dry matter (DM) content was determined with O'HAUS Halogen dryer MB35 (Ohaus Corporation, Parsippany, USA) at $105^{\circ} \mathrm{C}$. All samples were analysed in triplicate. The whey separation was determined with a Büchner funnel. The samples were weighed and then left to drain for an hour at room temperature. The volume of the collected whey was determined with a measuring cylinder. The results were converted into whey $\mathrm{mL} / 100 \mathrm{~g}$ yoghurt/h.

\section{Gel strength}

The structure of yoghurt was measured with TA. XT Plus (Stable Micro Systems, Great Britain) texture analyser. The samples were tempered to $10{ }^{\circ} \mathrm{C}$, the measurement was made with a $20 \mathrm{~mm}$ diameter cylinder probe. The gel strength was the force recorded at $10 \mathrm{~mm}$ penetration depth. Data evaluation was performed with the software of the Texture Exponent 32 instrument.

\section{Gel electrophoresis}

Molecular weight distributions of low-fat $(1.5 \%)$ set type yoghurt and separated whey fractions were analysed by SDS-PAGE according to Laemmli protocol (Laemmli et al., 1970) using $15 \%$ resolving gel and $6 \%$ stacking gel with Mini-PROTEAN 3Cell (Bio-Rad, Hercules, USA). Yoghurt and filtered whey samples $(10 \mu \mathrm{L})$ were diluted in Laemmli sample buffer (1:14) and loaded
(3 $\mu \mathrm{L} /$ lane) onto the gel. Separation was done at $200 \mathrm{~V}$ for $60 \mathrm{~min}$ at room temperature. After electrophoresis, the separated proteins were fixed on gel with $20 \%$ TCA (trichloroacetic acid) for $20 \mathrm{~min}$, and then the gel was soaked in acetic acid/ethanol washing liquid. The separated proteins were stained with Coomassie Brilliant Blue R-250 (Reanal, Hungary). The background staining was removed by $10 \%$ acetic acid. The bands were evaluated manually using Quantity One 4.2.1. software.

\section{Sensory evaluation}

After aging overnight at $10{ }^{\circ} \mathrm{C}$ the samples were evaluated with a trained panel (8-10 members) focusing on textural attributes of yoghurt. The essential textural attributes of yoghurt products as "porcelain", "spoonability", "smoothie after stirring" and "no syneresis" were ranked on a 0-100 score scale established by our department.

\section{Statistical analysis}

Linear regression was used to compare the objective (gel strength) and subjective ("porcelain" with sensory evaluation) properties of the final products.

\section{Results and discussion}

\section{Monitoring lactic acid fermentation}

Figure 1 shows the changes in $\mathrm{pH}$ and apparent viscosity during fermentation. The incubation of yoghurt samples was terminated at $\mathrm{pH} 4.8$ to

Figure 1. Effect of enzyme dosage on $\mathrm{pH}$ and apparent viscosity during fermentation

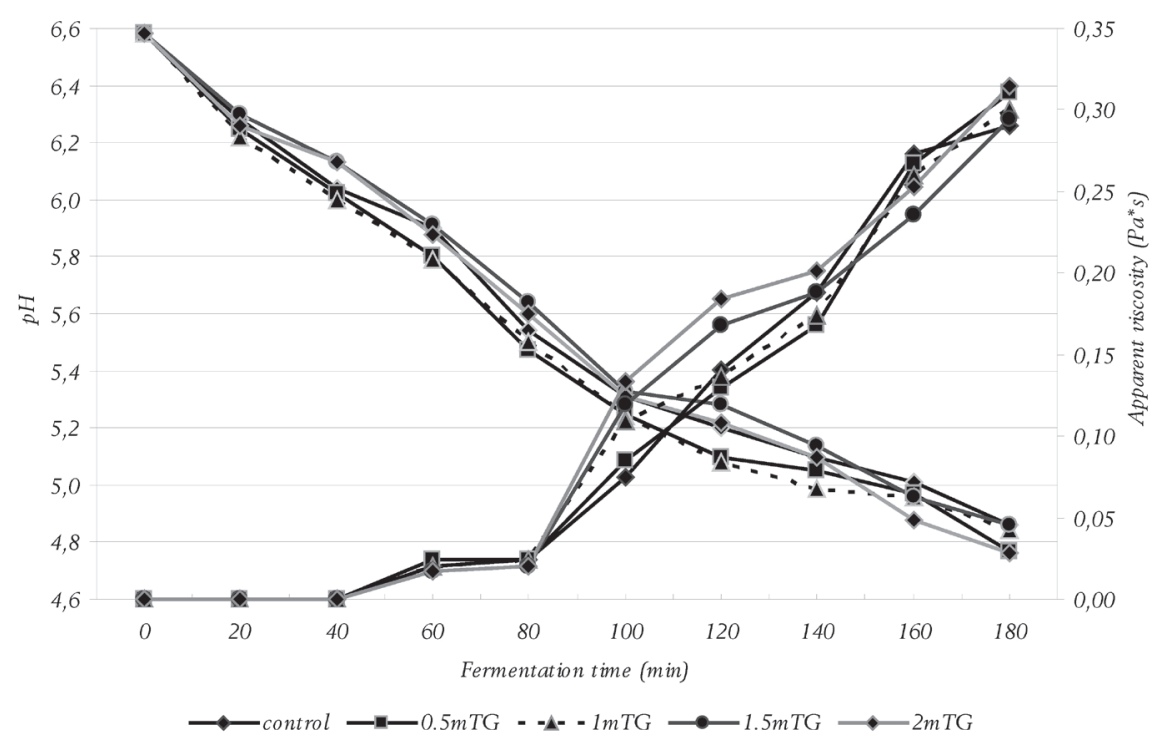


avoid over-acidification which was successful because we observed no whey separation of the experimental yoghurts. The decrease in $\mathrm{pH}$ during lactic acid fermentation was not influenced by the applied enzyme dosage. This result is in accordance with findings of Romeih et al. (2014). The gel development was followed with rotational viscometry. The enzyme treatment did not affect the sol-gel transformation which began after $40 \mathrm{~min}$ at $\mathrm{pH} 6.0$, where a slight increase in viscosity could be detected. The gelling process speeded up after $80 \mathrm{~min}(\mathrm{pH} \mathrm{5.5 \pm 0.07)}$ and followed a linearly increasing tendency until $180 \mathrm{~min}$ ( $\mathrm{pH} 4.96 \pm 0.05)$. The gelling properties of yoghurts made with $1.5 \mathrm{U} / \mathrm{g}$ and $2 \mathrm{U} / \mathrm{g}$ protein $\mathrm{mTG}$ had higher apparent viscosity values after 100 and 120 min than the samples with lower enzyme dosage. This high dosage of mTG has high affinity to form isopeptide bonds with $\beta$-casein of the outer layer of the casein micelle (Partschefeld et al., 2009), which enhances the stability of micellar structure. This difference was recognisable only until $140 \mathrm{~min}$, which is due to the fact that the time needed to reach the enzymesubstrate balance depends on the amount of enzyme.

\section{Characteristics of yoghurt and whey}

The dry matter content, $\mathrm{pH}$ and whey separation of manufactured $1.5 \%$ set-type enzyme treated and control yoghurts are given in Table 1 . The dry matter content of yoghurt was increasing with the enzyme addition, which caused a decreasing tendency in the dry matter of separated whey (separation method described in "Characteristics of yoghurt and whey" section). The most common method to observe syneresis is the centrifugation method (Romeih et al., 2014), although it seems to be more real to let the whey drainage occur in its natural way with gravity using the method described above. Results of whey separation demonstrated that the higher the enzyme dosage the denser the protein network and this retains more whey in the gel structure (Table 1).

\section{Gel strength}

Gel strength was measured as a function of force measured at $10 \mathrm{~mm}$ penetration depth (Figure 2). The increasing enzyme concentration led to increasing gel strength in a linear way, which was also proved to be significant with paired t-probe $(\alpha=0.05)$. According to our data the addition of $\mathrm{mTG}$ at 0.5 or $1 \mathrm{U} / \mathrm{g}$ protein level did not cause significant change in the gel firmness. According to our results the enzyme dosage above $1.5 \mathrm{U} / \mathrm{g}$ protein led to a gel strength twice as high as that of the control.

\section{Gel electrophoresis}

Due to the cross-binding enzyme activity high molecular mass polymers (>200 kDa) emerged (Fig. 3), which was also observed by others (De Jong and Koppelma, 2002; O'Sullivan et al., 2002; Tang et al., 2005; Van-Den Truong et al., 2004; Ozer et al., 2007; Hassan et al., 2007) as shown on Lane 5-8. A decrease was observed in $\alpha$-casein and $\beta$-casein bands of treated yoghurt samples containing mTG in increasing concentrations (see Lane 10-13). Traces of $\beta$-casein bands were reduced in the whey of the same yoghurts beside the bands related to whey proteins. The direct incubation of active MTG simultaneously with yoghurt starter culture led to formation of high amounts of casein dimers and trimers reported by Guyot and Kulozik (2010), which was observed in our SDS-PAGE yoghurt separation profile where mTG treatment resulted in the appearance of $50-150 \mathrm{kDa}$ polymers. The mTG enzyme cannot be seen at

Table 1. Main characteristics of set-type yoghurts made with $1.5 \%$ ESL milk and different enzyme dosage

\begin{tabular}{ccccc}
\hline & \% DM yoghurt & \% DM whey & $\mathrm{pH}$ & $\begin{array}{c}\text { Whey separation } \\
\text { whey } \mathrm{mL} / 100 \text { g yoghurt } / \mathrm{h}\end{array}$ \\
\hline control & $10.60 \pm 0.30$ & $6.79 \pm 0.16$ & $4.65 \pm 0.05$ & $19.05 \pm 0.06$ \\
\hline $0.5 \mathrm{mTG}$ & $11.16 \pm 0.07$ & $6.58 \pm 0.30$ & $4.64 \pm 0.04$ & $20.92 \pm 0.01$ \\
\hline $1 \mathrm{mTG}$ & $11.90 \pm 0.30$ & $6.47 \pm 0.08$ & $4.61 \pm 0.06$ & $13.69 \pm 0.05$ \\
\hline $1.5 \mathrm{mTG}$ & $12.21 \pm 0.25$ & $6.40 \pm 0.21$ & $4.66 \pm 0.05$ & $18.67 \pm 0.04$ \\
\hline $2 \mathrm{mTG}$ & $13.26 \pm 0.41$ & $6.29 \pm 0.24$ & $4.63 \pm 0.07$ & $15.64 \pm 0.03$ \\
\hline
\end{tabular}

Values are means of triplicate analyses of three individual yoghurt samples $(n=15), \pm$ standard deviation 
$38 \mathrm{kDa}$ (see the Activa YG reference at Lane 14), because even at the highest dosage ( $2 \mathrm{U} / \mathrm{g}$ protein) only $0.06 \mathrm{w} / \mathrm{v} \%$ enzyme preparation was added.

\section{Sensory evaluation}

Development of porcelain structure and spoonability of yoghurt samples were noticed at and above $1.0 \mathrm{U} / g$ protein enzyme level. Although $1.5 \mathrm{U} / \mathrm{g}$ and 2 $\mathrm{U} / \mathrm{g}$ protein $\mathrm{mTG}$ addition caused granulous structure after stirring which is possibly due to overdose of mTG (Figure 4). According to our results the panellists could not differentiate between the control and $0.5 \mathrm{U} / \mathrm{g}$ protein mTG samples concerning these attributes.

\section{Linear regression}

The objective (gel strength) and subjective ("porcelain") factors revealed a high correlation $\left(\mathrm{R}^{2}=0.99\right)$ between these two parameters between $0-1 \mathrm{U} / \mathrm{g}$ protein $\mathrm{mTG}$ addition (Figure 5).

\section{Conclusion}

This study demonstrated that the addition of $\mathrm{mTG}$ below $1.5 \mathrm{U} / \mathrm{g}$ protein did not have a significant effect on $\mathrm{pH}$ and viscosity during fermentation. With 0.5 and $1 \mathrm{U} / \mathrm{g}$ protein level creamy and smooth texture can be achieved without grains. We would also highlight that enzyme treatment led to a significant increase in the dry matter content by all enzyme dosages. Electrophoretic study revealed that this was due to the formation of high amounts of casein dimers and trimers.From the economical point of view it is important to know that a change from $1 \mathrm{U} / g$ protein to $0.5 \mathrm{U} / \mathrm{g}$ protein did not lead to significant differences in gel firmness or textural acceptance of low-fat settype yoghurt.

Figure 2. Changes in gel strength as a function of enzyme dosage in low-fat (1.5\%) yoghurt

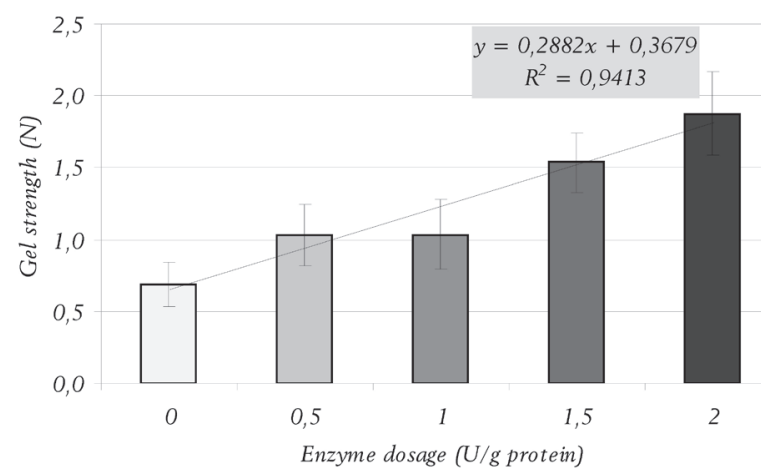

Figure 3. Gel electrophoresis with 15\% SDS-PAGE (Lane 1: MW standard 250 - $2 \mathrm{kDa}$ ]; Lane 2: casein; Lane 3: $\alpha$-lactalbumin (lower), $\beta$-lactoglobulin (upper); Lanes 4: control yoghurt; Lanes 5-8 low fat (1.5\%) yoghurts with mTG $(0.5,1,1.5,2$ U.g-1 protein). Whey of the same yoghurts in same order are presented on Lane 9 (control), and Lanes 10-13 (enzyme-treated) respectively. Lane 14: Activa YG

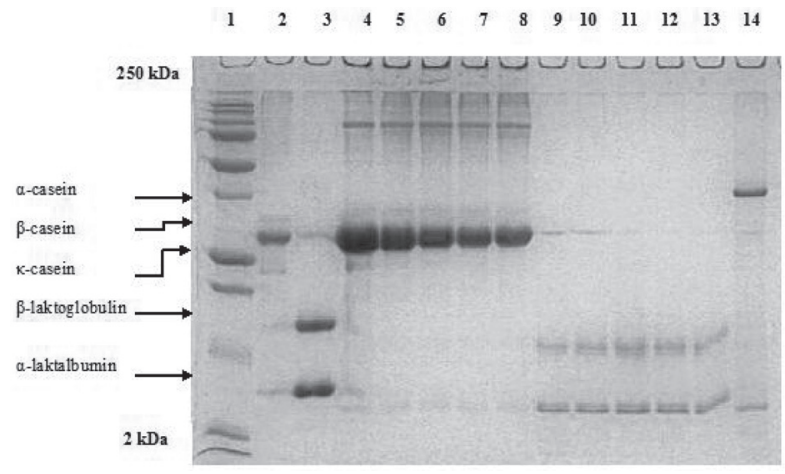

Figure 4. Changes of sensorial properties of low-fat $(1.5 \%)$ yoghurt samples with different enzyme doses

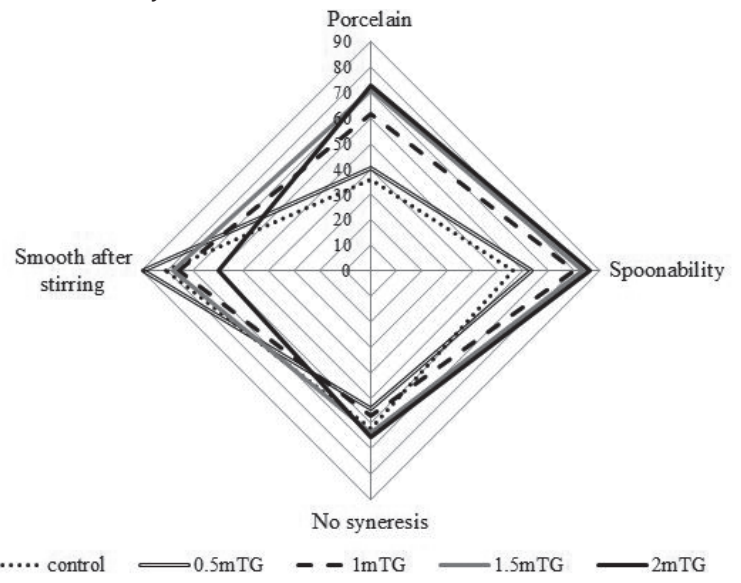

Figure 5. Linear regression of gel strength (objective) and porcelain (subjective) attributes

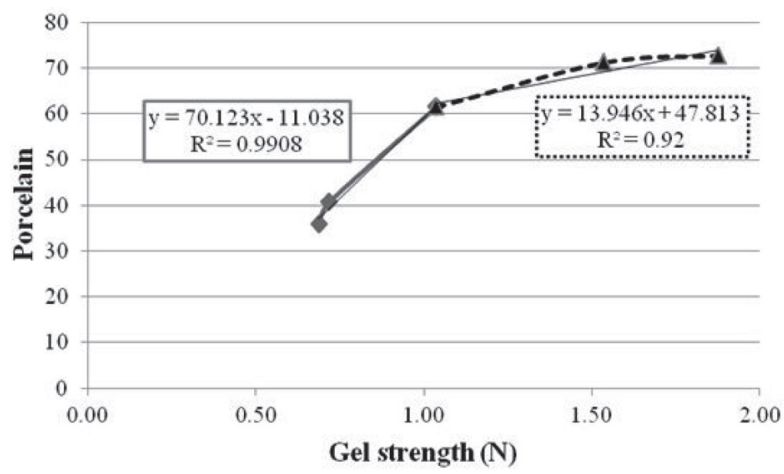




\section{Utjecaj dodatka mikrobne transglutaminaze na teksturalna svojstva jogurta}

\section{Sažetak}

Cilj ovog rada bio je utvrditi utjecaj dodatka 0,5-2 U/g mikrobne transglutaminaze (mTG) na $\mathrm{pH}$ i viskozitet jogurta tijekom fermentacije, te promjenu strukture proteina, čvrstoću gruša i senzorska svojstva malomasnog jogurta s dodatkom voća. Komercijalna mTG je dodana u nekoliko koncentracija $(0,5-2,0 \mathrm{U} / \mathrm{g})$ u mlijeko (1.5\% mliječne masti) zajedno sa DVS kulturom. Istraživanjem je utvrđeno kako dodatak enzima nije imao utjecaj na razvoj $\mathrm{pH}$ i viskozitet jogurta tijekom fermentacije, ali je dodatak mTG utjecao na zadržavanje sirutke (do $38 \%$ ), dok je čvrstoća gruša bila veća za $44 \%$.

Ključne riječi: fermentacija, malomasni jogurt, transglutaminaza, čvrstoća gruša, viskozitet, senzorska procjena

\section{References}

1. Bönisch, M.P., Huss, M., Lauber, S., Kulozik, U. (2007): Yoghurt gel formation by means of enzymatic protein cross-linking during microbial fermentation, Food Hydrocolloids 21, 585-595. doi: 10.1016/j.foodhyd.2006.07.002

2. Demirkaya, A.K., Ceylan, Z.G. (2009): The effect of microbial transglutaminase on microbiological, chemical, textural and sensory properties of yoghurt, Australian Journal of Dairy Technology 64, 171-176.

3. De Jong, G.A.H., Koppelma, S.J. (2002): Transglutaminase catalysed reactions impact on food applications, Journal of Food Science 67, 2798-2806. doi: 10.1111/j.1365-2621.2002.tb08819.x

4. Færgemand, M., Sørensen, M.V., Jørgensen, U., Budolfsen, G., Qvist, K.B. (1999): Transglutaminase: effect on instrumental and sensory texture of set style yoghurt, Milchwissenschafft 54, 563-566.

5. Gauche, C., Tomazi, T., Barreto, P.L.M., Ogliari, P.J., Bordignon-Luiz, M.T. (2007): Physical properties of yoghurt manufactured with milk whey and transglutaminase, LWT - Food Science and Technology 42, 239-243. doi: 10.1016/j.lwt.2008.05.023

6. Guyot, C., Kulozik, U. (2011): Effect of transglutaminase-treated milk powders on the properties of skim milk yoghurt, International Dairy Journal 21, 628-635. doi: 10.1016/j.idairyj.2010.10.010

7. Hassan, A.B., Osman, G.A., Babiker, E.E. (2007): Effect of chymotrypsin digestion followed by polysaccharide conjugation or transglutaminase treatment on functional properties of millet proteins, Food Chemistry 102, 257-262. doi: 10.1016/j.foodchem.2006.04.043
8. Iličić, M.D., Carić, M.Đ., Milanović, D., Dokić, L.P., Đurić, M.S., Bošnjak, G.S., Duraković, K.G. (2008): Viscosity changes of probiotic yoghurt with transglutaminase during storage, Acta Periodica Technologica 39, 11-19. doi: 10.2298/APT0839011I

9. Laemmli (1970): Cleavage of structural proteins during the assembly of the head of bacteriophage T4, Nature 227, 680-685.

10. Lorenzen, P.C., Schlimme, E. (1998): Auswirkung der enzymatischen Quervernetzung von Milchproteinen auf die resultierenden Eigenschaften von Joghurterzeugnissen, Kieler Milchwissenschaftliche Forschungsberichte 51, 89-97. doi: 10.1046/j.1471-0307.2002.00065.x

11. Lorenzen, P.C., Neve, H., Mautner, A., Schlimme, E. (2002): Effect of enzymatic cross-linking of milk proteins on functional properties of set-type yoghurt, International Journal of Dairy Technology 55, 152-157.

12. Neve, H., Lorenzen, P.C., Mautner, A., Schlimme, E., Heller, K.J. (2001): Effects of transglutaminase treatment on the production of set skim milk yoghurt: microbiological aspects, Kieler Milchwissenschaftliche Forschungsberichte 53, 347-361.

13. Ozer, B., Kirmaci, H.A., Oztekin, S., Hayaloglu, A., Atamer, M. (2007): Incorporation of microbial transglutaminase into non-fat yoghurt production, International Dairy Journal, 17, 199-207. doi: 10.1016/j.idairyj.2006.02.007

14. Partschefeld, C., Schreiner, J., Schwarzenbolz, U., Henle, T. (2009): Studies on Enzymatic Crosslinking of Casein Micelles, Czech Journal of Food Sciences 27, S99-S101.

15. Romeih, E.A., Abdel-Hamid, M., Awad, A.A. (2014): The addition of buttermilk powder and transglutaminase improves textural and organoleptic properties of fat-free buffalo yoghurt, Dairy Science and Technology 94, 297-309. doi: 10.1007/s13594-014-0163-8

16. Sanl1, T., Sezgin, E., Deveci, O., Senel, E., Benli, M. (2010): Effect of using transglutaminase on physical, chemical and sensory properties of settype yoghurt, Food Hydrocolloids 25, 1477-1481. doi: 10.1016/j.foodhyd.2010.09.028

17. Tang, C., Yang, X., Chen, Z. (2005): Physicochemi$\mathrm{cal}$ and structural characteristics of sodium caseinate biopolymers induced by microbial transglutaminase, Journal of Food Biochemistry 29, 402-421. doi: 10.1111/j.1745-4514.2005.00038.x

18. Van-Den, T., Clare, D.A., Catignani, G.L. (2004): Cross-linking and rheological changes of whey proteins treated with microbial transglutaminase, Journal of Agricultural and Food Chemistry 52, 1170-1176. doi: $10.1021 /$ jf034397c

19. Wroblewska, B., Kaliszewska, A., Kołakowski, P., Pawlikowska, K., Troszynska, A. (2010): Impact of transglutaminase reaction on the immunoreactive and sensory quality of yoghurt starter, World Journal of Microbiology and Biotechnology 27, 215-227. doi: 10.1007/s11274-010-0446-Z

20. Yüksel, Z., Erdem, Y.K. (2010): The influence of transglutaminase treatment on functional properties of set yoghurt, International Journal of Dairy Technology 63, 86-97. doi: 10.1111/j.1471-0307.2009.00539.x 